\title{
The message of the Bible as testimony to the world
}

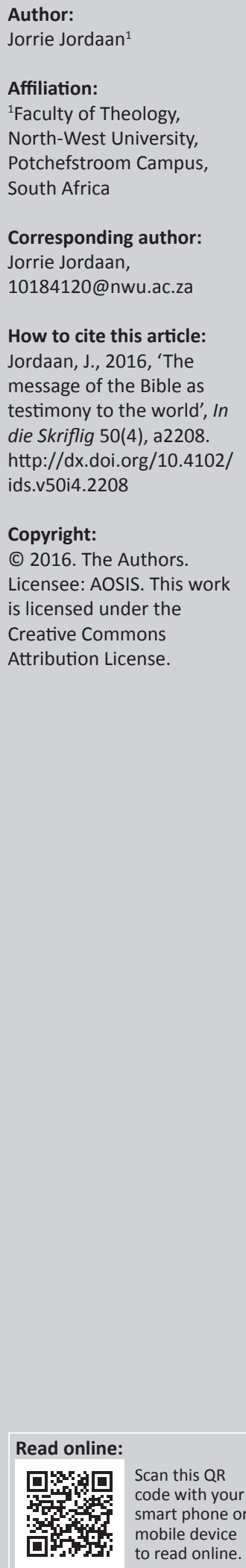

This festschrift is in honour of the valuable contribution of Prof. P.P. (Paul) Krüger at the Theological School Potchefstroom (TSP) and the Faculty of Theology of the North-West University (NWU) over the last 16 years. On 14 June 2016 Paul reached the age of 65 and in accordance with the agreement between the GKSA and the NWU he has to retire by the end of 2016 as professor at the TSP and the NWU.

In 2000 Paul obtained the PhD degree on the basis of his thesis: 'Die beskrywing van gedagtesamehang: 'n eksegetiese hulpmiddel, geillustreer aan die hand van Genesis 2' ['The description of thought cohesion: an exegetical aid, illustrated at the hand of Genesis 2']. Since then he has made a highly valued contribution to his field of study by the publication of various scientific articles in journals, chapters in joint publications and numerous papers he read at national and international conferences.

Before Paul was called and appointed as professor at the TSP and the NWU Faculty of Theology in 2000, he served as minister of the Gereformeerde Kerk, Alberton-Wes (1979-1982), Brackenhurst (1982-1996) and Brackenhof (1996-2000). During these years he also served in various deputy groups of the General Synod of the GKSA and was especially involved in the activities of Christian Education, also and particularly through his leading role at ARSO (Aksie Reformatoriese Skoolonderwys). Over the years Paul wrote various books and articles on a great variety of general theological issues that were published in popular Christian publications. For one term he was a member of the editorial board of Die Kerkblad of the GKSA, and from 2003 to 2005 editor-in-chief of In die Skriflig.

As an expression of gratitude for the wonderful gifts Paul had received from the Lord and put to use in the church and the academic world, the articles in this festschrift, all written by colleagues and students, were collected to be presented in Paul's honour. Although the festschrift was not planned with a specific formulated theme in mind, the variety of contributions can be brought together under the theme 'The message of the Bible as testimony to the world'.

H.F. (Herrie) van Rooy, in his article, presents the results of his research into rhetorical aspects of the prophecies of Ezekiel. Although the rhetorical aim and situation of prophetic books have been investigated by scholars quite frequently, this article is based on a new approach. It attempts to reconstruct the possible original rhetorical situation of those instances where the prophet uses quotations and react on them. Thereby Van Rooy succeeds to bring together three fields of investigation in Old Testament scholarship: the study of rhetorical aspects, quotations in the Bible, and so-called disputations.

P.C. (Chris) van der Walt takes Deuteronomy 20 as a departure point for his article. He formulates a biblical perspective on decisions of the Geneva Convention on matters of natural environment. Especially their formulated views regarding the prolongation of human lives, are scrutinised. On the basis of Deuteronomy 20 Van der Walt derives a biblical perspective on the relation between humankind and nature. This perspective is in stark contrast to the convictions of that time and also challenges conventional views of our time regarding human-nature relations. The article ends in a plea for a paradigm shift away from the current anthropocentric attitude towards nature and the right to live. Instead a new set of moral rules should be established in which the prolongation of human lives should not be pursued to the detriment of nature.

Cynthia Miller-Naudé and Jacobus Naudé wrote their article about a very specific aspect of biblical Hebrew grammar. In various linguistic theories the status of the adjective as a grammatical category is debated. Many grammar books deny that the adjective in biblical Hebrew is a category distinct from substantives. Approaching the matter from both morphological and 
syntactical perspectives, they come to the conclusion that nouns and adjectives in biblical Hebrew are indeed distinctive lexical categories and should not be subsumed under the category of 'substantive' or 'nomen'.

The contribution of Paul J. de Bruyn and Ben de Klerk relates to the practical side of a minister's work in the church. The article is based on the results of a thesis in Pastoral Theology that was submitted in 2015, which deals with effective and responsible leadership of Afrikaans-speaking ministers. Ministers in Afrikaans churches do not have properly defined and clearly described guidelines on what is expected of them as leaders in the church. Therefore, this article takes applicable guidelines from the actions of Paul as leader and apostle in die New Testament. Especially communications relevant to this matter that Paul wrote in Philippians 3:1-16, are taken as point of departure.

Paul R. McCuistion, in his article, focuses on statements that are made in the Gospel of Matthew about fulfilment of Old Testament prophecies regarding the Messiah. The author begins his investigation in the very first words of the Gospel where Jesus is made known as the Christ, son of David and son of Abraham (Mt 1:1). His article then continues with an investigation of seven passages in Matthew's Gospel that are introduced by $\pi \lambda \eta \rho o ́ \omega$ and other fulfilment formulas. The conclusion of the article is that Matthew indeed understood the Old Testament prophecies in Christological sense and used the prophecies as support in identifying Jesus as the Messiah.

In her article, Amanda du Plessis makes an analysis of the Lord's Prayer and applies it to the terrain of pastoral counselling. She demonstrates how the individual believer in the process of counselling at the hand of this prayer can be guided to shift from a problem-focussed attitude to a life of justice, peace and joy. In the article two main themes from the Lord's Prayer are discussed in particular: human beings' relationship with God, and their dependence on God for life. In this way the Lord's Prayer is presented as a paradigm for restorative justice in brokenness.

Aida Spencer's contribution consists of an investigation into the linguistic style and rhetoric form of Paul's communication during his court case at Caesarea, as recorded in Acts 15 and 26. Her conclusion is that the Greek used by Paul when speaking with Festus and Agrippa, demonstrates a definite literary style in which Paul, consciously or subconsciously, chose certain linguistic possibilities in Koine Greek to attain emphasis, analogies and other rhetorical effects.

Flip Buys and John Koning made a contribution that involves the spreading of the gospel in a society that is constantly growing in urbanisation and influenced by postmodernism. From a study of the sermons of Reformed Baptist ministers and ministers of the Reformed Churches in South Africa, they find that these church communities prove to be passionately committed to the biblical truth and orthodoxy. Yet, a definite need for justified and effective contextualisation is identified, as preachers seem to resist contextualisation, probably considering it a compromise with liberal theology. The article concludes with proposals for justified contextualisation with a view to a more effective outreach to postmodernist urban people.

The contribution of Pierre Jordaan results from his studies of the Old Testament apocryphal writings. In the article, he makes an analysis of the role that suffering bodies play in the narratives implied in 2 Maccabees 3. By applying the narrative therapeutic approach of Epston and White, he comes to the conclusion that the narratives in 2 Maccabees 3 indicate that God responds positively when the high priest and the nation are united in their worship, and when they are willing to counter foreign invaders in the temple and to fend off their ideologies.

G.J.C. (Jorrie) Jordaan, in his contribution, investigates the statement in Hebrews 12:24 that the sprinkled blood speaks of better things than the blood of Abel. By means of comparison to relevant information elsewhere in Scripture, especially the history of Cain and Abel in Genesis 4, he comes to the conclusion that the blood of the murdered Abel was witness to the fact that after the fall the entire humankind are conceived and born in sin, and therefore destined for judgement and punishment by God. However, the blood of animals that were sacrificed according to the stipulations of God's covenant and had to be sprinkled over God's people (Ex 24:8), was a witness to God's promise of reconciliation and forgiveness of sins. This promise came to fulfilment in Jesus Christ, so that Jesus is called, inter alia in Hebrews 12:24, the Mediator of a new covenant. 